\title{
The Benefits of Educational Tales in Teacher and Student Perspective
}

\author{
Muhammad Nur Wangid \\ Department of Primary Education, Program Pascasarjana, Universitas Negeri Yogyakarta. \\ Jalan Colombo No. 1, Karangmalang, Yogyakarta 55281, Indonesia \\ Corresponding Author. E-mail: m_nurwangid@uny.ac.id \\ Received: 12 July 2018; Revised: 10 August 2018; Accepted: 9 October 2018
}

\begin{abstract}
This study aimed at analysing teacher and student perspectives on educational fairy tales as instructional learning materials. In order to analyse the perspective, the researcher involved 20 teachers and 400 students from the fourth grade of elementary school in the Province of Yogyakarta Special Region within his study. The data collection techniques that had been used were questionnaires and interviews while in analysing the data the researcher used descriptive statistical data analysis technique. The descriptive statistical data analysis technique was used in order to describe the perception of teachers and students about the benefits of educational tales. The description itself was displayed in percentage. The results of the study then show that both teachers and students have highly positive perspective on the presence of educational fairy tales as learning support for the teaching materials. Within the study, it is found that the teacher perspective is $91.50 \%$ while the student perspective is $98.00 \%$ in terms of attractiveness of educational fairy tales. Next, in terms of the utilization of educational fairytale books as teaching materials, the teacher perspective is $92.50 \%$ while the student perspective is $93.00 \%$. Furthermore, in terms of usefulness for building character values, the teacher perspective is $97.75 \%$ while the student perspective is $86.00 \%$ with "Very Good" category for both. Last but not the least, in terms of utilization aspect of educational fairy tale for developing the cognitive ability of the children, the teacher perspective is $92.00 \%$ while the student perspective is $88.75 \%$ with "Very Good" category. These results imply that both the teachers and the students have high perspective on the fact that a fairy tale containing educational elements is able to generate sense of interest, to generate learning usefulness, to serve as a medium of character values within children, and to stimulate the development of cognitive abilities among children.
\end{abstract}

Keywords: benefits of educational tales; teacher and student perspective

How to Cite: Wangid, M. (2018). The benefits of educational tales in teacher and student perspective. Jurnal Prima Edukasia, 6(2), 196-202. doi:https://doi.org/10.21831/jpe.v6i2.21795

Permalink/DOI: https://doi.org/10.21831/jpe.v6i2.21795

\section{Introduction}

Science and Mathematics are compulsory subjects in elementary school that play important role in developing the students' cognition such as increasing curiosity, observing environment, developing intellectual abilities, and building fundamental experience in order to understand broader concepts of science and mathematics. The ideal science and mathematics learning therefore needs to be supported by teaching materials, especially in primary schools. A number of theories explain that teaching materials need to have the ability to explain theories to students in an easy way.

Teaching materials are systematically arranged components that displays some of the competencies that students should master (Dick, Carey, \& Carey, 2009). Based on the statement, the goal of teaching materials that both teachers and academics have arranged is to facilitate students in mastering a competence. Teaching materials consist of 3 (three) types namely printed material, visual material and audio material (Prastowo, 2013, p. 138). Most schools in the Province of Yogyakarta Special Region use printed materials developed by the academics who work under the Ministry of Education. The thematic textbooks are the main print materials that have been used in all elementary schools that implement the 2013 Curriculum, including the ones in the Province of Yogyakarta Region. Government Regulation Number 19 Year 2005 Article 43 paragraph (5) states that, "The content 
worthiness, language, presentation and subject textbook graphic are assessed by BSNP and stipulated by Ministerial Regulation". The criteria of eligibility standards include content, language, presentation, and graphic aspects. Nevertheless, a number of questions have been arising with regards to how the thematic role of the teacher is viewed as practitioners and students as readers. The aspects such as legibility, attractiveness, and ease of understanding need to be examined in order to reveal whether there is a need for complementary teaching materials or not and how the form of the complementary teaching materials should look like.

A preliminary study that was conducted to find out the responses of teachers and students in thematic books used in schools has found a number of facts that have implications on the conclusions of several aspects from the incomplete teaching materials. The preliminary study involved a number of teachers and students as the subjects that have been gathered from 5 (five) public primary schools in Yogyakarta Province. In order to focus the response analysis, the preliminary study was limited to teachers and students in the fourth grade of the elementary schools that implement the Curriculum 2013 within the Province of Yogyakarta Special Region Yogyakarta Province. The results of the preliminary study reveal 4 (four) aspects of the teaching materials' worthiness in terms of teacher and student perspective which covers the aspects of content, language, presentation, and graphics. The results might be consulted in the Figure 1.

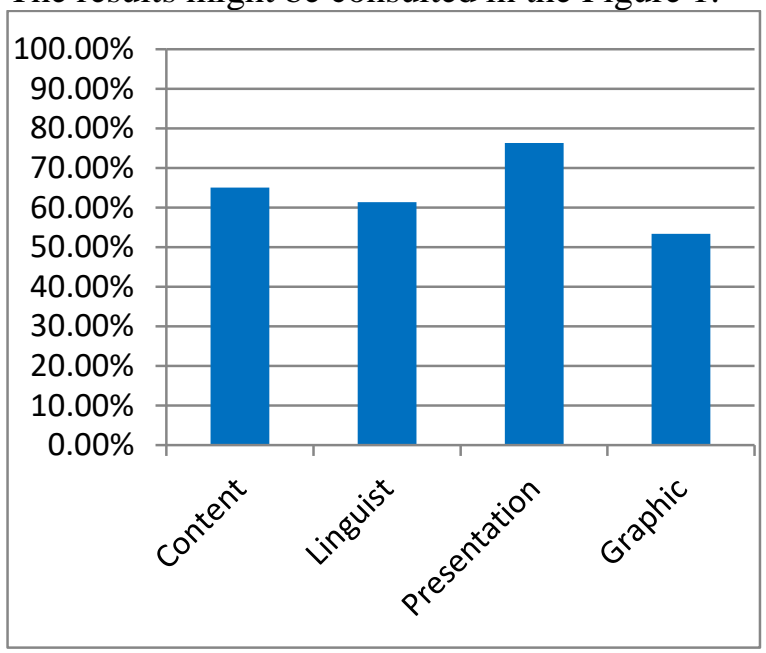

Figure 1. Teacher \& Student Response Charts on Thematic Books

Based on the above results, it might be concluded that from the expected standard $(100 \%)$ the aspects of presentation yield the highest figure (76\%) while the rest of the aspects yield under-expectation figure: ease of material to be understood (65\%), readability $(61 \%)$ and design attractiveness (53\%). These figures mean that in the view of teachers and students the thematic books still do not fill the needs of teachers and students as practitioners and readers. The results of the preliminary study finally solve the first question namely that there is still a need for complementary teaching materials to support the learning process in primary schools.

In relation to the results of the preliminary study, there are 13 criteria of ideal textbook for children namely: (1) having a clearly used concept; (2) relevant to the curriculum; (3) attracting the reader's attention; (4) being able to motivate the reader; (5) stimulating learners activities; (6) having attract illustration; (7) understanding must be preceded by appropriate communication; (8) content to support other subjects; (9) respecting individual differences; (10) trying to establish the values prevailing in society; (11) considering linguistic aspects according to the ability of learners using; (12) not using mistify concept; and (13) having a clear point of view (Tarigan \& Tarigan, 2009, p. 20). According to Tarigan's point of view on the ideal textbook criterion, it might be assumed that the ideal textbook needs to give the reader the benefit of experiencing a new experience that adds knowledge and is interesting to read.

In addition to the previous criteria, there are literacy criteria for children that have been commonly used in the Canada and Asia Pacific regions namely: (1) the ability to provide motivating and challenging experiences appropriate to the age, social and social development of the learner; (2) the ability to evoke sensitivity of critical responses; (3) the ability to create wellstructured knowledge; (4) the ability to have reading qualities; (5) the ability to use effective and responsive language and use the daily language; (6) the ability to open the way for students to understand social, historical, geographic and cultural diversity; and (7) the ability to develop sensitivity and understanding that reflect individual differences (Foundation for the Atlantic Canada English Language Arts Curriculum, 1996). These criteria refer to how textbooks should be read by children and they do not only have wide range of material but also wide range of reflection stimulation, self-concept formation and sensitivity to the surrounding environment. This particular criterion has actually been presented in the thematic book but 
due to the unfulfilled eligibility (readability, attractiveness and ease of matter) in the reader's view, the character education material becomes blurred.

Both the view of Tarigan and the view of Foundation for Atlantic Canada of ELA imply that reading is able to continually stimulate the reader's child to read while the content (material $\&$ character education) in the book gives a new experience to the reader. As a consequence, reading becomes not only interesting but also easy to understand, so that the content in the book is well conveyed only by reading the book either independently or structured in the learning activities.

In future classes, textbooks will contain assignments that include problem solving and research and analysis; in the same time, the learning activities of these textbooks will rely on prominent literature in various manner (Pahl \& Rowsell, 2005, p. 139). Therefore, it is possible that the complementary materials might be science books of fiction or adventure tales that students are interested in. In other words, adventure stories will provide an opportunity to enable the packaging of subject matter in one story that can bring students to cognitive and character improvement through problem solving approach.

A survey conducted by Mitchell, Waterbury, \& Casement (2002) has found that both male and female elementary school-age children like fictional adventure reading. Adventure fiction books are always interesting to read not only for children but also for adults. The sense of interest will make the children motivated to read more and increasingly believe in the contents of the book. However, another question might arise about how useful it is.

Fictional stories have all-encompassing power that might command emotions and force engagement and endless reading. This is one of the ways in which thinking skills, foundations of organizing information and ideas, understanding culture and stimulation of human consciousness are exercised (Livo, 2003, p. 3). Stories refers to how people know, remember and understand something. By understanding story, readers might understand a phenomenon presented in the story. If the story is about war, then the reader will also be invited to know the strategy of war. Living the nuances in war, and taking wisdom in the story. Stories of any kind give readers the opportunity to gain new experiences and new knowledge simultaneously.
In relation to story, fairy tale refers to the forms of fictional story that has close proximity to the children. Thus, a fairy tale which has educational values might be a referential form of development for teaching materials. However, it is important to understand how important the book of fairy tales is within the students' and the teachers' perceptions as both of them are subjects who have close proximity to the story. Departing from the above elaboration, the study is conducted in order to reveal how educational fairy tales as teaching materials in the views of teachers and students. The purpose of the study is to understand the perspective of teachers and students about the attractiveness of educational fairy tales as teaching materials, the use of educational fairy tales as learning materials, the effectiveness of educational fairy tales on the formation of children's character values, and the usefulness of educational fairy tales on cognitive development of children.

\section{Method}

The study was a survey research that used cross-sectional design. The purpose of using the design was to collect teacher and student perspective about the benefit of using educational tale as teaching materials in single activity. This research was conducted in 2017.

\section{Research Sampling}

The population of the research was the teachers and the students of Grade IV Elementary Schools in the Province of Yogyakarta Special Region. The research involved 20 teachers and 400 students as the respondents. All respondents in the research was selected by means of purposive sampling technique. Specifically, the samples should be from the elementary schools that became the pilot project of 2013 Curriculum implementation.

\section{Data Collecting}

For the data collection, two techniques were implemented namely questionnaire distribution and interview. The questionnaires were distributed to the students and the teachers in order to obtain the overview on the usefulness of story books from the perspective of teachers and students. The data that had been collected were in quantitative form and then were classified into four categories as follows: very good, good, fair, and poor. On the other hand, the interview was performed only to the teachers in order to identify the teacher's perspective on the function of the 
Jurnal Prima Edukasia, 6 (2), July 2018 -199

Muhammad Nur Wangid

storybook in assisting and simplifying the learning process that has been carried out.

Data Analysis

In the data analysis, descriptive techniques were used in order to determine the level of perception on the usefulness of story books by means of percentage. Every aspect was calculated in order to determine the category.

\section{Results and Discussion}

Based on the results of the questionnaire distribution and the interview that have been conducted to 20 teachers and 400 students, it is found that both the teachers and the students display largely positive perspective on the presence of fairy tale books as the supporting material for the learning process conduct. These results might be consulted in the Table 1 .

Based on the results in Table 1 , it is apparent that both the teachers and the students have positive perspective on the use of educative fairytale books as supporting material in learning process. Then, the perspectives are elaborated as follows: $91.50 \%$ teachers and $98.00 \%$ teachers' state that the attractiveness of educational fairy tales belong to the "Very Good" category while $92.50 \%$ teachers and $93.000 \%$ teachers state that the use of educational fairy tales in the learning process belong to the "Very Good" category. Furthermore, $97.75 \%$ teachers and $86.00 \%$ students' state that the usefulness of educational fairy tales to inculcate the character values among the children belong to the "Very Good" category. Last but not the least, $92.00 \%$ teacher and $88.75 \%$ students state that the cognitive abilities of the children after the use of educational fairy tales belong to the "Very Good" category. A better description of the survey results might be seen in Figure 2.

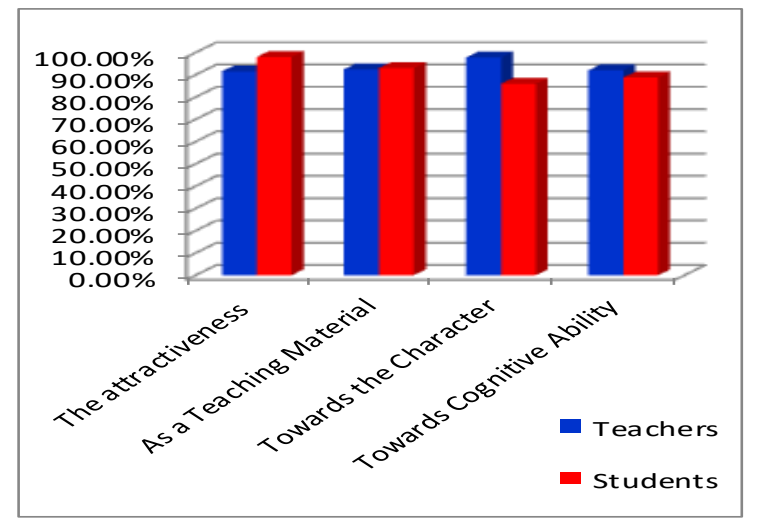

Figure 2. Teacher and Student Perspective

The results of the above survey show that from the teachers' and the students' point of view the use of educational fairy tales have several benefits. In terms of attractiveness, fairy tales in the forms of literary works are considered very interesting, especially if these literary works contain elements of education. The attractiveness of educational fairy tales in this case might be found in the following component: (1) display and illustration of books; (2) stories and figures presented; and (3) communicative language presentation. Saxby \& Winch (1991, p. 10) states that a good book will make the reader hear, feel and see. Referring to the idea, it might be concluded that a good book is able to make the readers hear, feel, and see. According to the teachers and the students, fairy tale books are good because these books are able to stimulate their sense of hearing, feeling and seeing especially if these books contain more interesting educational elements. Especially for the students, they will not only be entertained and imagined with the the elements of fantasy presented in the fairy tales but also be provided with the educational values reflected in them. The emergence of a high sense of interest from students to educational fairy tales might be a trigger for the meaningfulness of the students' learning when they use fairy tale books.

Table 1. Teacher and Student Perspective

\begin{tabular}{lcccc}
\hline \multirow{2}{*}{ Aspect } & \multicolumn{4}{c}{ Perspective } \\
\cline { 2 - 5 } & Teacher & Category & Student & Category \\
\hline The Attractiveness of the Educative Tales & $91.50 \%$ & $\mathrm{~A}$ & $98.00 \%$ & $\mathrm{~A}$ \\
The Use of Educational Tale as a Teaching Material & $92.50 \%$ & $\mathrm{~A}$ & $93.00 \%$ & $\mathrm{~A}$ \\
$\begin{array}{l}\text { The Use of Educational Tale towards the Values of Child } \\
\text { Character }\end{array}$ & $97.75 \%$ & $\mathrm{~A}$ & $86.00 \%$ & $\mathrm{~A}$ \\
$\begin{array}{l}\text { The Benefits of Educational Tale towards Child's Cognitive } \\
\text { Ability }\end{array}$ & $92.00 \%$ & $\mathrm{~A}$ & $88.75 \%$ & $\mathrm{~A}$ \\
\hline
\end{tabular}


Fairy tale books that contain educational element will also be very useful as supporting material for the learning process especially if the materials presented in them are a subject matter that the students are learning. The materials in a lesson that might be brought by fairy tale is able to provide a sense of interest to students, to provide convenience to students in understand the material, and to generate meaningfulness of students in learning process. Therefore, based on the survey results it might be concluded that both the teachers and the students have good perspective on the use of fairy tales that present the subject matter. As a result, these fairy tales might be used as supporting learning materials that will not only entertain the students but also facilitate and generate meaningful learning process to the students.

The use of the fairytale books as the medium for delivering the subject matter has been previously studied by Andersone (2009). The results of his study show that fairy tales include a number of notions that help children to get mathematical notions about the surrounding world and also its variety and glory. Fairy tales develop not only the children's imagination but also develop the children's skills in benefitting mathematical connections and basic notions within simple and understandable language in primary and preschools mathematics education while putting stress on these connections and alike in the systemic course of mathematics. The tale includes a number of ideas that help children gain math knowledge about the world around them. The tale not only develops children's imagination but also develops their skills to use these math connections. In addition, the use of fairy tale as a medium for conferring subject matter has also been studied by Ipriansyah (2011) and the results of his study prove that fairy tales might be used as means of both entertainment and education. Through fairy tales, children will attain entertainment as well as the educational values contained in it; that also includes the function of fairy tales as the medium delivering the given subject matters.

In the perspective of teachers and students, it is also known that fairy tales containing educational elements might have positive impact on students' cognitive abilities. Tales that contain adventure elements might bring new experience to the children their imagination. In the stage of development, elementary school-age children need more imaginative books that have story line so that the children might experience and find knowledge through the process of a fun imagination as they are reading the fairy tales. Furthermore, fairy tales strengthen the power of emotion, develop the power of imagination, train the memory, and exercise the reason (Kready, 2004, p. 11). The tale strengthens the emotional power, develops the power of the imagination, retains the mind, and trains the students to be able to construct a reason. This means that the children's fairy tales are able to develop their thinking skills including imagination, recall, to reason, thus directing the child to have critical thinking skills.

Through the fairy tale, the children's critical thinking ability might be stimulated as the fairy tales provide opportunities for the children to solve problems and make decisions from the results of their analysis on the story in the fairy tales. In this regard, a goal of using fairy tales as creative case examples is to deepen the students' understanding of the often-complex nature of ethical decision making. Case examples might be used as a vehicle to assist students in developing problem-solving skills (Henderson \& Malone, 2012, p. 69). Through their experiences with fairy tales, the critical cases that have been presented might assist the students in understanding complex problems and become a consideration in making decisions. In other words, fairy tales might be used as the medium for developing problem-solving skills among the children. Thereby, fairy tales are able to develop the children's mental processes since the children will be facilitated in making decisions on the given issue. Being skilled in making rational, relevant, and logical decisions is part of the critical thinking aspect; thus, it is implicitly understood that the child's critical thinking ability can be developed through fairy tales.

In addition, the fairy tale is also an action or a wise and intelligent way to educate and advise the child (Utomo, 2013, p. 24). Fairy tales might provide desired impact on the children's need for imaginations and fantasies. Children will have more fun in listening to fairy tales containing advice and teachings or upbringing. These positive desires and attitudes will certainly have an impact on the child's personal development. Therefore, fairy tales might serve as a medium for internalizing the values of characters among the students as having been shown by the perspective of both the teachers and the students. The implication is that, in addition to providing a strength, the fairy tale also gives pleasure to the child since fairy tales bring joy into child life. The mission of joy has not been fully preached, but it 
is widely known that joy works toward physical health, mental brightness, and moral virtue (Kready, 2004, p. 9). It appears that fairy tales might bring pleasure in the children's life. The pleasure is not only to be perceived but also to have an effect on the physical health, mental development, and moral of the child. Thus, fairy tales provide an opportunity for children to build their personality from the experiences they experience through reading.

Students will understand the values or messages conveyed in fairy tales through their emotional experiences. A critical consideration of the messages that fairy tales and stories may carry (Tesar, Kupferman, Rodriguez, \& Arndt, 2016, p. 1). The exemplary message contained in fairy tales is usually hidden or implied e.g. in the form of images or persuasive stories.

Thus, a fairy tale provides an opportunity for the children to perform reflection by themselves and to be the part of the fairy tale in order to stimulate their emotion so that they will live the example of the experience in the fairy tale. Referring to this, it might be understood that as a literary work fairy tales are an effective medium for internalizing various moral values, characters, social norms, and ethics to children. Through the fairy tale, empathy and exemplary character can be grown. Hopefully, the value and the message might be applied by the child in his daily life. In the same time, fairy tales provide the context where the relationships between people are very simple and depicted in a comprehensible manner for young readers. The children will be able to discern the rights and the wrongs since evil characters are always punished and thus it serves as a distracting example for them

Almost every fairy tale carries the moral messages. It is a proof that fairy tales are not a mere entertainment but also educate (Mikešová, 2006, p. 7). Reflecting on that opinion, the fairy tales provide a context for the relationships between figures that are described simply to be understood by the child. The child will gain an understanding that the guilty person will get a result or punishment, while the good will get happiness. This serves to give exemplary to the child about positioning himself a good character. This illustrates that almost all fairy tales carry a moral message, this is proof that the fairy tale is not only an entertainment but also educational.

The fairy tale as a medium to internalize the children's character values has been proven earlier by the results of a study by Order in 2013 . The results of this study show that fairy tale has a good impact on the spiritual and cognitive development of children. In addition, the results of this study also show that the fairy tales provide opportunities for children to understand the conflicts in the story that they might enhance the spiritual and intellectual experience. Based on the results of the research, the next step that needs to be done is to develop a book of fairy tales that can empirically facilitate the cognitive, psychomotoric, and affective aspects of children in an integrated way through a science-based book that provides opportunities for children to develop the three aspects through various learning activities.

\section{Conclusion}

Based on the survey results, it is apparent that teachers and students have very positive perspective on the use of educational fairy tale books supporting materials in the learning process. It is found that $91.50 \%$ teachers and $98.00 \%$ students state "Very Good" category for the attractiveness of educational fairy tales. Both the teachers $(92.50 \%)$ and the students $(93.00 \%)$ also view that educational fairy tales have enormous usefulness in learning process, one of which is to serve as supporting materials. In addition, both the teachers $(97.75 \%)$ and the students $(86.00 \%)$ also have the view that fairy tales are able to serve a medium for internalizing the character values. Then, on the usefulness of the educative fairy tales to the childrens' cognitive abilities also get positive responses from both teachers and students. $92.00 \%$ teachers and $88.75 \%$ students state "Very Good" category for the usefulness of the educative fairy tales for the children's cognitive abilities. This means that both the teachers and the students have high perspective on the fact that fairy tales containing educational elements might create a sense of interest, might provide usefulness in learning, might be a medium of internalizing character values in children and might stimulate children's cognitive abilities.

Teachers might use books of fairy tales that contain educational values in learning process as instructional learning materials to help students understand the subject matter being studied and to give meaningfulness to students. Furthermore, teachers might use books of fairy tales as a medium for internalizing the character values and for stimulating the development of students' cognitive abilities

\section{References}

Andersone, R. (2009). Through fairy-tales to math in the lessons. Acta Didactica 
Napocensia, 2(2), 111-118.

Dick, W., Carey, L., \& Carey, J. O. (2009). The systematic design of instruction. New York, N.Y.: Pearson.

Henderson, K. L., \& Malone, S. L. (2012). Ethical fairy tales: Using fairy tales as illustrative ethical dilemmas with counseling students. Journal of Creativity in Mental Health, 7(1), 64-82. https://doi.org/10.1080/15401383.2012.66 0128

Ipriansyah, I. (2011). Peran dongeng bagi perkembangan dan pembentukan kepribadian anak. Ta'dib: Journal of Islamic Education (Jurnal Pendidikan Islam) (Vol. 16). Retrieved from http://jurnal.radenfatah.ac.id/index.php/ta dib/article/view/55

Kready, L. F. (2004). A study of fairy tales. Houghton Mifflin.

Livo, N. J. (2003). Bringing out their best: Values education and character development through traditional tales. Libraries Unlimited.

Mikešová, L. (2006). The usage of fairy tales in English lessons and their influence on childrens social development. Univerzita
Pardubice.

Mitchell, D., Waterbury, P., \& Casement, R. (2002). Children's literature: An invitation to the world. Allyn \& Bacon.

Pahl, K., \& Rowsell, J. (2005). Literacy and education: Understanding the new literacy studies in the classroom. Paul Chapman.

Prastowo, A. (2013). Pengembangan bahan ajar tematik tinjauan teoritis dan praktik. Yogyakarta: Diva Press.

Saxby, H. M., \& Winch, G. (1991). Give them wings: The experience of children's literature. Macmillan Co. of Australia.

Tarigan, H. G., \& Tarigan, D. (2009). Telaah buku teks bahasa Indonesia. Bandung: Angkasa.

Tesar, M., Kupferman, D. W., Rodriguez, S., \& Arndt, S. (2016). Forever young: Childhoods, fairy tales and philosophy. Global Studies of Childhood, 6(2), 222233.

https://doi.org/10.1177/204361061664764 2

Utomo, S. B. (2013). Mendongeng dalam perspektif pendidikan. Agastya: Jurnal Sejarah Dan Pembelajarannya, 3(01). https://doi.org/10.25273/ajsp.v3i01.901 